\title{
Revolution as herald of new bliss in early English romantic poetry
}

\author{
Svetlana Borisovna Koroleva ${ }^{1 *}$, Marina Ivanovna $\mathrm{Nikola}^{2}$, Elena Nikolaevna \\ Chernozemova $^{3}$, and Ekaterina Dmitrievna Kolesnikova ${ }^{4}$ \\ ${ }^{1}$ Linguistics University of Nizhny Novgorod, The International Research Laboratory of Basic and \\ Applied Aspects of Cultural Identification, Nizhny Novgorod, Russia \\ ${ }^{2}$ Moscow Pedagogical State University, Department of World Literature, Moscow, Russia \\ ${ }^{3}$ Moscow Pedagogical State University, Department of World Literature, Moscow, Russia \\ ${ }^{4}$ Central Russian University, Central Russian Institute for the Humanities and Technology, Obninsk, \\ Russia
}

\begin{abstract}
The idea that the Great French Revolution for the age of early English Romanticism is a signal for mankind to transition into a new era, into a new apocalyptic time of the end of human history, is considered established in modern literary studies. At the same time, such issues remain underdeveloped as the relationship between the images of the Golden Age, paradise regained, and New Jerusalem in the poetry of Elder English Romantic poets and the interpretation of modernity in its connection with the past in the context of a biblical myth. The search for answers to these two questions is the goal of this research. The study is conducted within the framework of comparative literary studies with elements of comparative cultural studies. The significant results include the ideas that the human history during the early poetry by Elder English Romantic poets is depicted as mankind's transition from blissful primordial harmony of the unity of the person-in-love with nature and another person to the oppressed-divided internal (spiritual) and external (social and political) state and, finally, to the new external (free) and internal (spiritually harmonious) bliss. In this new image of human history, the biblical myth of the Last Judgment and the New Jerusalem is superimposed on the idea of the return of the Golden Age and, simultaneously, paradise lost, and is interpreted through enlightenment ideas and romantic philosophy and aesthetics. The Great French Revolution seems to be the precursor of not only the common longing for the new bliss but also the transformation of human nature on the way to returning to the righteous state of sacrificial love.
\end{abstract}

Keywords: images of paradise, early poetry of Elder English Romantic poets, Great French Revolution

\footnotetext{
* Corresponding author: svetlakor0808@gmail.com.
} 


\section{Introduction}

The idea that the Great French Revolution for the era of early English romanticism was a sign of the transition to the apocalyptic time of the end of human history is established. It is clearly articulated in the "Apocalyptic expectations by preachers and poets" section of the Anthology of English Literature [1]. This idea is also found in the monograph and individual literary articles [2-5]. At the same time, such issues remain underdeveloped as the relationship between the images of the Golden Age, paradise regained, and New Jerusalem in the poetry of Elder English Romantic poets and the interpretation of modernity in its connection with the past in the context of a biblical myth.

Finding answers to these two questions is the purpose of this study.

\section{$2 \quad$ Methods}

The study is conducted within the framework of comparative literary studies with an emphasis on a comparative analysis of the images of the Golden Age, the paradise returned, and the New Jerusalem in the early poems of the Elder English romantic poets. This analysis is carried out based on the cultural and historical context of the era with the connection of elements of comparative cultural studies. An important element of the research methodology is semiotic analysis aimed at identifying the distinctive nature of the functioning of the selected images in connection with the features of educational and romantic philosophy.

\section{$3 \quad$ Results and discussion}

The Great French Revolution holds a special place in the works of its contemporaries - the "Elder" English romantic poets. It is defined both by the consistency of the very theme of the French Revolution in the early poetry by Wordsworth, Coleridge, Blake, and Southey and by its deeply mythological interpretation. Each of these poets portrayed the Great French Revolution equally consistently both as an event leading to the acquisition of a paradise lost and the return of the Golden Age and as a breakthrough to a new, unprecedented bliss.

In W. Wordsworth's early poem "The Prelude" (1798-1805), the motive for the return of mankind (Europe) to the Golden Age is voiced here as a premonition - in the words about France which is on the very brink of "golden hours" [6:346]. The biblical apocalyptic allusion to the complete "rebirth" of human nature (And human nature seeming born again) after the Last Judgment turns out to be integral to it. The French Revolution appears as the return of "virgin", original natural bliss in W. Wordsworth's another early work of "Descriptive Sketches" (the 1793 version): "Nature, as in her prime, her virgin rein/Begins...". At the same time, it seems to the poet that "a new-made heaven" welcomes the birth of "new earth" [7: 150]. In a later philosophical poem "Excursion" (first published in 1814), the persona directly points to the perception of the French Revolution through the ancient myth of the "Golden Age": the Revolution becomes for the persona the return of "Saturnian rule" - "a progeny of golden years" [8: 444].

The motive for the return of bliss in connection with the theme of the French Revolution was no less characteristic of S.T. Coleridge's early poetry. In the "Religious Musings" (17941796), the motive is directly expressed in the call "O Return!", with which the author-persona refers to "Pure Faith" and "meek Piety" [9: 2]. The poem ends with the assertion of the coming universal salvation (Universal Redemption; Time is no more), the first step towards which, according to the poet, is the French Revolution [9: 13, 23].

The return of mankind to a blissful state is interpreted in W. Blake's early poem "The French Revolution" (1791) as the coming acquisition of freedom, light, and knowledge by 
the souls of people [10]. In W. Blake's other early poem, "The Marriage of Heaven and Hell" (1790-1793), the author-narrator directly states, "Now is the dominion of Edom, and the return of Adam into Paradise" [11].

Modernity in the early poetry by Elder English romantics (as well as in the religious and philosophical speeches of English thinkers) was a herald not of a simple closure of the historical cycle on the return of the bliss to mankind but rather a leap-breakthrough into the unprecedented - to New Jerusalem, to the eternal reign of Christ [12].

The images of the "end times" and "new dawn" are the most important in two revolutionary poems by W. Blake "The French Revolution" and "America: a prophecy" (1793) $[10 ; 13]$. The French Revolution also marked a complete rebirth of mankind for R. Southey: "Old things seemed passing away, and nothing was dreamt of but the regeneration of the human race", the poet wrote to his wife Caroline Bowles in his mature years [14].

The biblical myth turned out to be a model of human history, the main plot-semantic moments of which were associated with certain stages in the formation of society and consciousness. The starting point of the movement - the stay of the primeval people in Eden - was rethought in the spirit of Rousseau's philosophy as a pre-civilizational state of man. In Coleridge's "Religious Musings", the "pre-civilizational" bliss of man is described using the images of "the primeval age", "the vacant Shepherd", "the green grass" [9: 18], etc. Similarly, the naturalness of the initial happy state of man is emphasized in W. Blake's poetry. It is no coincidence that Adam's bliss in paradise is violated in Blake's poem "The Song of Los" (1795) by the restrictions that Urizen imposes on man. Having completely historical forms Socratic and Platonic philosophy, the Bible and the Koran, the materialistic-mechanistic philosophy of Newton and Locke - these restrictions deprive man of natural health, the state of love and joy, and the feeling of the eternity of being [15].

The blissful inner state of the primeval people also fell into the focus of the poetic depiction, thus the Rousseauist motives became significantly deeper. In Southey's poem "Joan of Arc" (1796), the time of the blissful state of people is depicted as "that blest era of the infant world" - the era in which "Love and Happiness went hand in hand", and sin has not yet created "Those artificial boundaries that divide/Man from his species" [16: 148].

In Wordsworth's "Descriptive Sketches", the blissful "infant" time of mankind (he was Nature's child) is associated with the absolute freedom of man (Once Man entirely free) not subject to any laws except the laws of reason and desire (Confessed no law but what his reason taught,/Did all he wished), corresponding to the image of the Creator (He, all superior, but his God disdained; wished but what he ought) [7: 150]. A necessary condition for bliss in the poem is the presence of a person in nature, which turns out to be the "keeper" of the divine truth about happiness and harmony.

The second stage of the historical movement in the biblical myth was depicted in the works of the Elder English romantic poets as the loss of man's blissful state due to the emergence of human society. The main property of society was the oppression of a person through the establishment of various social institutions and norms. At the same time, the romantic poets, unlike the thinkers of the Enlightenment, were searching for the reasons for oppression in society primarily within a person.

Oppression in Coleridge's poem "Religious Musings" is associated with the awakening of proprietary interests in a person. The consequence of these desires is the emergence of "Property", and then the rise to power of "Warriors", "Lords" and "Priests". Selfish desires are portrayed as generating sins, which, in turn, suppress the human soul, deprive the soul of true knowledge. The oppression of the human soul in Coleridge's poem turns out to be inextricably linked with socio-political oppression [9: 20].

The name Cain plays an important role in characterizing a person of this historical stage. So that "no Cain injures uninjured" [9: 16], an angel should watch what is happening on earth in Coleridge's poem. For Coleridge, Cain turns out to be the prototype of a man of the 
civilization period, a man who has forgotten his unity with those who are like him in God. At the same time, the creation and development of society and the state appear in Coleridge's poem as a natural stage in the development of human history. It is the development of goodness in sin and creative potential in blindness that leads humanity to the final stage of human history: the French Revolution, associated with a new kingdom of bliss. These sprouts of the new in Coleridge's poem, on the one hand, are associated with the personality and teaching of Christ [9: 20, 22] - and this shows the poet as an heir of the Christian tradition, and on the other - with the ideas of the Enlightenment, with scientific achievements - and this shows Coleridge as a man of the era of the French Revolution. Newton, Hartley, Priestley appear in the poem as sages and saints, leading people to universal salvation [9: 22].

In Southey's poem “Jeanne D'Arc", oppression is also inextricable and dual: on the one hand, oppression is determined by a person's inner sinfulness, one's willingness to separate oneself from the "others". The prototype of such a person for Southey, as well as for Coleridge, is the image of Cain [16: 148]. On the other hand, oppression has a specific external manifestation in society in the form of the domination of "Wealth and Power", which, in turn, deprive not only the human body but also the human soul of freedom.

The two-part oppression in a civilized society is depicted in Wordsworth's "The Prelude" in the images of a society that oppresses freedom and the creative nature of man ("Oppression under which even highest minds/Must labor, whence the strongest are not free!") and in the images of "internal oppression" of man with wrong thoughts and feelings, far from nature ("sorrow, disappointment, vexing thoughts, confusions of the judgment" "that had turned aside from Nature's way") [6: 351, 363-364]. The sprouts of happiness for man are hidden in Wordsworth's poem not in the movement of human thought and spirit but the appeal to nature, its divine harmony.

In Blake's poem "The French Revolution", the idea of deep human oppression in society is revealed in the allegorical images of the seven towers of the Bastille: the towers named Horror, Darkness, Religion, Order, Destiny, God, and Bloody. Each of the towers simultaneously embodies the method and result of the suppression of the human spirit: the prophet is turned into a slave by horror, a mystic - by order, a woman - by religion, etc. Blake's external and internal forms of oppression are the same as those of other "Elder" romantic poets inextricably linked with each other.

The final stage of human history in the poetry of the Elder English romantic poets has, as indicated above, a clear impress of modernity: the main sign of a breakthrough to a new bliss is socio-political freedom and the struggle for it; The French Revolution is the forerunner of this breakthrough. At the same time, with the acquisition of external freedom, poets foreshadow the transformation of human nature itself - the transformation "promised" in the Apocalypse.

In Coleridge's poem Ode to the Departing Year (1796), Liberty acquires the status of divinest, carrying with it Justice and Truth [17]. In Southey's poem "Joan of Arc", Theodore predicts not only a general deliverance from oppression and poverty but also the triumph of Virtue, Love, Equality, and Wisdom [16: 149]. The hymn of Liberty and Freedom at the end of Wordsworth's "Descriptive Sketches" includes the glorification of virtue, love, truth, and justice, which should come after the social liberation of man [7: 150].

\section{Conclusion}

History in the early poetry by the Elder English romantic poets was depicted as a consistent transition of humanity from the blissful primitive harmony of love and unity to a divided state associated with selfish desires and social and state forms of human oppression and, finally, to a new bliss related to the return of external freedoms to man and an absolute transformation of human nature. In this grand image of human history, the biblical myth was seen through 
modern and past history and enlightenment ideas, and romantic philosophy and aesthetics. The event that gave the main impetus to such an understanding of human history was the Great French Revolution.

\section{References}

1. S. Greenblatt et al. (Eds.), Apocalyptic expectations by preachers and poets, in The Norton Anthology of English Literature, 2, 137-160 (W.W. Norton and Co, New York, London, 2000)

2. M.D. Paley, Apocalypse and Millennium in English romantic poetry (Clarendon Press, Oxford, 1999)

3. M.R. Sheikh, PARIPEX - Indian Journal of Research, 3(8), 1-2 (2014)

4. A. Craciun, Interdisciplinary studies in the long nineteenth century, 2 (2006). https://doi.org/10.16995/ntn.442.

5. M. Kovavisarach, The Keats-Shelley Review, 33, 130-133 (2019). https://doi.org/10.1080/09524142.2019.1611284

6. W. Wordsworth, The Prelude, in The Norton Anthology of English Literature, 2, 305383 (W.W. Norton and Co, New-York, London, 2000)

7. W. Wordsworth, From Descriptive Sketches, in The Norton Anthology of English Literature, 2 (W.W. Norton and Co, New-York, London, 2000)

8. W. Wordsworth, Excursion, in Complete Poems: in one volume, 403-525 (CreateSpace Independent Publishing Platform, Scotts Valley, 2017)

9. S.T. Coleridge, Religious Musings, in The Major Works, 13-22 (Oxford University Press, Oxford, 1985)

10. W. Blake, The French Revolution, in Complete poetical and prose works, 285-299 (J. Johnson, London, 1998)

11. W. Blake, The Marriage of Heaven and Hell, in The Complete Poetry and Prose, 3344 (Anchor, New York, 1982)

12. J. Priestley, From The Present State of Europe Compared with Antient Prophecies, in The Norton Anthology of English Literature, 2, 143 (W.W. Norton and Co, New-York, London, 2000)

13. W. Blake, America: a Prophecy, in The Complete Poetry and Prose, 51-59 (Anchor, New York, 1982)

14. E. Dowden, The Correspondence of Robert Southey with Caroline Bowles, in The Norton Anthology of English Literature, 2, 137 (W.W. Norton and Co, New York, London, 2000)

15. W. Blake, The Song of Los, in Complete Poetical and Prose Works, 67-69 (J. Johnson, London, 1998)

16. R. Southey, From Joan of Ark: An Epic Poem, in The Norton Anthology of English Literature, 2, 148-149 (W.W. Norton and Co, New-York, London, 2000)

17. S.T. Coleridge, Ode to the Departing Year, in The Major Works, 31-35 (Oxford University Press, Oxford, 1985) 